${ }^{\circledR}$ Entomologica Fennica. 3.XII.1990

\title{
Heavy metal concentrations in males and females of three pine diprionids (Hymenoptera)
}

\author{
Kari Heliövaara, Rauno Väisänen, Eero Kemppi \& Martin Lodenius
}

\begin{abstract}
Heliövaara, K., Väisänen, R., Kemppi, E. \& Lodenius, M. 1990: Heavy metal concentrations in males and females of three pine diprionids (Hymenoptera). — Entomol. Fennica 1:175-179.
\end{abstract}

Heavy metal concentrations $(\mathrm{Cu}, \mathrm{Fe}, \mathrm{Ni}, \mathrm{Cd})$ in the cocoons of three gregarious pine diprionids, Gilpinia socia, Diprion pini and Neodiprion sertifer, were compared between the species and sexes. The sawflies were reared in the laboratory in colonies from the first instar larvae, being fed on Scots pine (Pinus sylvestris) needles collected from a heavily polluted or a relatively unpolluted site. The levels of copper, iron and nickel were two to three times as high in $N$. sertifer as in the two other species. Cadmium showed bioaccumulation in all three species. In N. sertifer and G. socia reared on polluted needles, the metal concentrations were higher in males than in females.

Kari Heliövaara and Eero Kemppi, Finnish Forest Research Institute, P.O. Box 18, SF-01301 Vantaa, Finland

Rauno Väisänen, Water and Environment Research Institute (Nature Conservation), P.O. Box 250, SF-00101, Helsinki, Finland

Martin Lodenius, Department of Environmental Conservation, University of Helsinki, SF-00710 Helsinki, Finland

\section{Introduction}

High levels of heavy metals have been reported for various invertebrates near smelters and other pollutant sources (e.g. Bengtsson \& Rundgren 1984, Beyer et al. 1985, Hopkin et al. 1986, Heliövaara et al. 1987). Recent studies on species in the same trophic level show that the concentrations of heavy metals may be connected with a specific physiology (van Straalen \& van Wensem 1986, Heliövaara et al. 1987). Metal concentrations have not been compared previously between the two sexes of the same pterygote species, though differences observed between individuals in size and developmental time suggest that heavy metals absorbed in larval food could later show different levels in the two sexes.
The objective of the present article is to compare concentrations of copper, iron, nickel and cadmium in cocoons between three gregarious pine diprionid species and between males and females within the species. The species investigated are Neodiprion sertifer (Geoffroy), Diprion pini (Linnaeus) and Gilpinia socia (Klug). All three feed on Scots pine (Pinus sylvestris L.) needles. G. socia and D. pini overwinter as cocoons in the soil, while $N$. sertifer overwinters at the egg stage on pine needles. Their larval time is about six weeks but the timing of the larval period and the age of the needles preferred by the larvae depend on the species (Table 1). In diprionids, the females are usually larger than the males. There are also differences in the number of larval instars between the species and sexes. 
Table 1. Life history characteristics of the three gregarious diprionid species studied (according to PschornWalcher 1982 and Viitasaari \& Varama 1987).

\begin{tabular}{|c|c|c|c|c|c|c|}
\hline & \multicolumn{2}{|c|}{ Number of instars } & \multirow{2}{*}{$\begin{array}{l}\text { Larval } \\
\text { period }\end{array}$} & \multirow{2}{*}{$\begin{array}{c}\text { Age of needles } \\
\text { preferred }\end{array}$} & \multicolumn{2}{|c|}{ Adult length, mm } \\
\hline & Males & Females & & & Males & Females \\
\hline Gilpinia socia & 4 & 5 & VII-VIII & old & $6.5-8.0$ & $7.0-9.5$ \\
\hline Diprion pini & 5 & 6 & VII-VIII & old + new & $7.0-9.5$ & $7.5-10.5$ \\
\hline Neodiprion sertifer & 4 & 5 & VI -VII & old & $6.0-9.5$ & $7.0-10.5$ \\
\hline
\end{tabular}

\section{Material and methods}

The concentrations of copper, iron, nickel and cadmium were determined separately on male and female cocoons of the diprionids. The cocoons resulted from two simultaneous laboratory rearings, each containing a colony of 60 first instar larvae of N. sertifer (in June-July), 55 larvae of $D$. pini (in July-August) and 24 larvae of $G$. socia (in July) in four replicates. One set of the larvae was fed with polluted, and the other set with clean needles. The polluted needles originated from western Finland near a metallurgical plant, and the unpolluted ones from north of Helsinki with no industry in the close vicinity. Pine shoots were collected from four pines on both the polluted and unpolluted sites. Each larval colony always received its food from one and the same pine. Larvae of $N$. sertifer were fed with the needles of the previous year, while those of the two other species were able to feed on needles of the current year as well. The rearing arrangement is described in more detail in Heliövaara et al. (1989).

The heavy metal $(\mathrm{Cu}, \mathrm{Fe}, \mathrm{Ni}, \mathrm{Cd})$ concentrations were determined individually on four male and four female cocoons from both rearings. Before analysis, the samples were dried in $105^{\circ} \mathrm{C}$. The pupae were digested in concentrated $\mathrm{HNO}_{3}$ (Suprapur or Aristar) $(1 \mathrm{ml} / 100 \mathrm{mg}$ of sample) in an aluminium block. The temperature was kept at $50^{\circ} \mathrm{C}$ for two hours and at $110^{\circ} \mathrm{C}$ for $16-18$ hours. One millilitre of $\mathrm{H}_{2} \mathrm{O}_{2}$ was added and the temperature was kept at $110^{\circ} \mathrm{C}$ for six hours. The digested samples were filtered and diluted with distilled water to 5 or $10 \mathrm{ml}$.

The same heavy metals were determined on the previous year's pine needles sampled in June. Approximately $1 \mathrm{~g}$ of needles was dry-ashed in $460^{\circ} \mathrm{C}$ for four hours. The ash was diluted in $10 \mathrm{ml}$
Table 2. Heavy metal concentrations $(\mu \mathrm{g} / \mathrm{g})$ in pine needles of the previous year used as larval food in the two laboratory rearings.

\begin{tabular}{lrrrr}
\hline & \multicolumn{2}{c}{ Polluted } & \multicolumn{2}{c}{ Unpolluted } \\
& mean & SD & mean & \multicolumn{1}{c}{ SD } \\
\hline $\mathrm{Cu}$ & 497.4 & 116.1 & 4.3 & 1.4 \\
$\mathrm{Fe}$ & 1081.9 & 226.3 & 83.6 & 17.6 \\
$\mathrm{Ni}$ & 141.9 & 26.0 & 1.8 & 2.0 \\
$\mathrm{Cd}$ & 1.3 & 0.4 & 0.2 & 0.1 \\
\hline
\end{tabular}

concentrated $\mathrm{HCl}$ (p.a.). The volume was adjusted to $5 \mathrm{ml}$ by evaporation, whereafter the samples were filtered and diluted to $25 \mathrm{ml}$ by adding distilled water. The metal contents were measured using flame and graphite furnace atomic absorption spectrometry (Varian SpectrAA 40 and Perkin Elmer 360).

\section{Results}

The heavy metal levels were much higher in the needles collected near the industrial plants (Table 2 ). The heavy metal concentrations in the two sexes and the two rearings are given for the three sawfly species in Fig. 1. In N. sertifer, the levels of copper were more than ten times as high and those of iron five times as high in the cocoons reared on polluted needles. In D. pini, the levels of copper were six times as high and those of iron three times as high in the insects reared on polluted needles. The difference between the rearings in the levels of these metals was smallest in G. socia, the concentrations being only two to three times as high in the rearings on polluted needles. In all 


\section{N. sertifer}
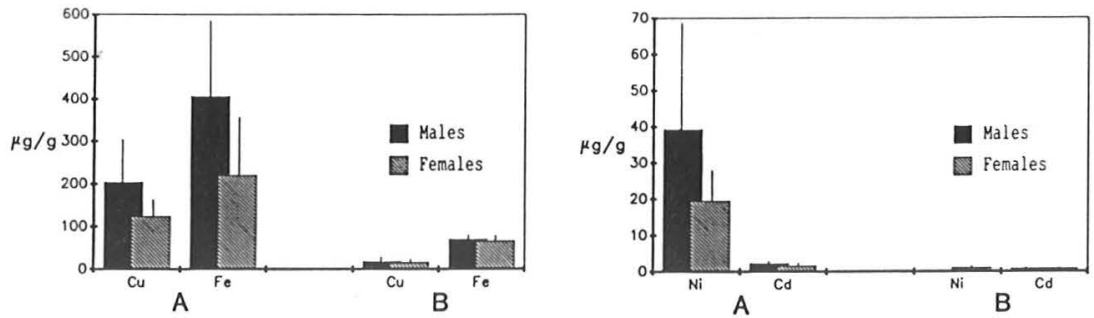

D. pini
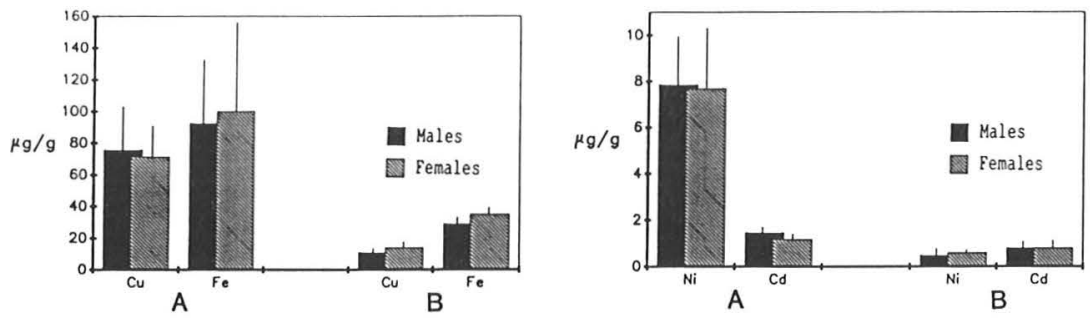

G. socia
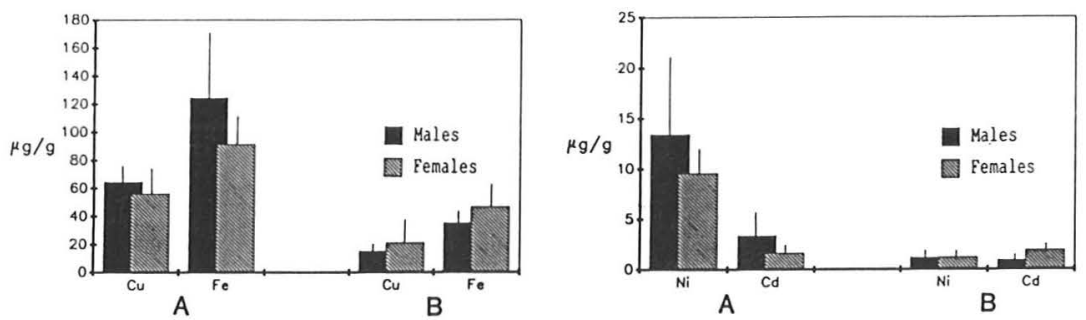

Fig 1. Concentrations of copper, iron, nickel and cadmium (mean, halved standard deviations) in male and female cocoons of the three pine diprionids fed on polluted (A) and unpolluted (B) needles.

three species, the levels of nickel were about ten times as high in the insects fed on polluted needles. The concentrations of cadmium differed rather little between the two rearings.

The concentrations of copper, iron and nickel were two to three times as high in $N$. sertifer as in the other two species. The level of cadmium was highest in $G$. socia and lowest in D. pini. In contrast to the other elements studied, the level of cadmium was higher in the cocoons of each spe- cies than in the needles (Table 2), indicating bioaccumulation.

In $N$. sertifer, all the heavy metals were at a higher level in the male cocoons, but the difference was not statistically significant. The same trend was observed in G. socia fed on polluted needles, but in the rearing on unpolluted needles the heavy metal levels were slightly higher in the female cocoons. No differences could be detected between the sexes in D. pini. 


\section{Discussion}

The differences in the heavy metal concentrations of the pine needles between the polluted and unpolluted site were reflected in the levels in the insects. The between-species variation could not be related to the number of larval instars, but the timing of the larval period or the utilization of different needle age classes can apparently explain some of the results. The early summer feeder N. sertifer (Kangas 1941, Juutinen 1967) had much higher concentrations of heavy metals than the two late summer feeders. $N$. sertifer feeds only on old needles, which are likely to have higher metal concentrations than the needles of the current year. In the present study area, the concentration of cadmium was higher (mean $1.2 \mu \mathrm{g} / \mathrm{g}$ ) in two-year-old pine needles than in one-year-old needles (mean $0.9 \mu \mathrm{g} / \mathrm{g}$ ). This was also the case with nickel, the corresponding values being 110 and $70 \mu \mathrm{g} / \mathrm{g}$ (Hynninen 1983). Although D. pini feeds on needles of both the previous and the current year (Eichhorn 1977, Geri et al. 1985), the heavy metal levels in this species were not markedly lower than in $G$. socia, which prefers old needles. The annual shoot growth of the pines in the polluted area was only $3-4 \mathrm{~cm}$ (Heliövaara \& Väisänen 1989a), and only a small fraction of the needles eaten by the two species was of the current year. Thus, we consider that the utilization of different needle age classes is not alone able to explain the large between-species variation, but that the species tend to concentrate different amounts of heavy metals due to some unknown physiological differences. The results obtained with some related sawfly species feeding on needles of the same age support this view. For example, up to four-fold differences in iron levels were observed between species with similar feeding habits (Heliövaara \& Väisänen 1989b).

Concentration of cadmium along the food chain has been reported, in the link between litter and earthworms (Hartenstein et al. 1980, Hunter \& Johnson 1982), and other invertebrates (Hunter et al. 1987). The cadmium concentrations of herbivorous insects have also been reported to be higher than those recorded for plants (Lindqvist 1988, Bengtsson 1989). However, Pihlajamäki et al. (1989) found that the level of cadmium in two sphingid moths was lower than or the same as in their larval food plants. This contradictory result may be due to their sampling procedure. Controlled laboratory rearings of one geometrid and one noctuid moth and of four diprionid sawflies have shown that cadmium does accumulate in several insects (Heliövaara \& Väisänen 1989b, 1990). The copper and iron levels were high in the sawflies, especially in $N$. sertifer, indicating that they play a role in the transfer of these metals to higher trophic levels. One possible pathway is from diprionids to shrews and other small mammals feeding on sawfly cocoons (see Olofsson 1987), and further to birds of prey and predatory mammals.

In natural conditions, there are only minor differences in heavy metal concentrations between the sexes in sawflies. In the insects fed on polluted needles, however, the concentrations were considerably higher in males than in females in both $N$. sertifer and G. socia. Since the material is limited, this observation deserves further study. Females moult one time more than males (PschornWalcher 1982), which possibly enables more efficient secretion of heavy metals. They also contain a large egg mass (Maeta et al. 1981). If eggs have low metal concentrations, this mass may have reduced the total concentration in females.

Acknowledgements. Miss Riitta Kojo, Mr. Esa Tulisalo and Mr. Martti Varama are thanked for assistance. Dr. Bo Långström is thanked for his comments on the manuscript. This study received financial support from the Finnish Acidification Research Project (HAPRO).

\section{References}

Beyer, W. N., Pattee, O. H., Sileo, L., Hoffman, D. J. \& Mulhern, B. M. 1985: Metal contamination in wildlife living near two zinc smelters. - Environ. Poll. Ser. A 38:63-86.

Bengtsson, G. \& Rundgren, S. 1984: Ground-living invertebrates in metal-polluted forest soils. - Ambio 13:29-33.

Bengtsson, B.-E., Elmquist, H. \& Nyholm, E. 1989: Några rön kring apollofjärilen i Sverige samt försök att förklara dess tillbakagång. - Entomol. Tidskr. 100:31-37.

Eichhorn, O. 1977: Autökologische Untersuchungen an Populationen der gemeinen Kiefern-Buschhornblattwespe Diprion pini (L.) (Hym.: Diprionidae) I. Herkunftsbedingte Unterschiede im Sclüpverlauf und Diapauseverhalten. - Zeitschr. Ang. Entomol. 82: 395-414. 
Geri, C., Allais, J. P., Goussard, F., Liger, A. \& Yart, A. 1985: Incidence de l'âge du feuillage sur le développement de Diprion pini L. (Hym. Diprionidae). Conséquences pour l'évolution des populations. Acta Oecologia / Oecol. Applic. 6:349-365.

Hartenstein, R., Neuhauser, E. F. \& Collier, J. 1980: Accumulation of heavy metals in the earthworm Eisenia foetida. - J. Environ. Qual. 9:23-26.

Heliövaara, K. \& Väisänen, R. 1989a: Interactions among herbivores in three polluted pine stands. - Silva Fennica 22:283-292.

- 1989b: Between-species differences in heavy metal levels in four pine diprionids (Hymenoptera) along an air pollutant gradient. - Environ. Poll. 62:253-261.

- 1990a: Heavy metal contents in pupae of the pine moths Bupalus piniarius and Panolis flammea (Lepidoptera: Geometridae and Noctuidae) near an industrial source. - Environ. Entomol. (in press).

Heliövaara, K., Väisänen, R., Braunschweiler, H. \& Lodenius, M. 1987: Heavy metal levels in two biennial pine insects with sap-sucking and gall-forming lifestyles. - Environ. Poll. 48:13-23.

Heliövaara, K., Väisänen, R. \& Varama, M. 1989: Cocoon measurements of gregarious pine sawflies (Hymenoptera, Diprionidae) reared on pollutant-stressed Scots pines. - Ann. Entomol. Fenn. 55:75-78.

Hopkin, S. P., Hardisty, G. N. \& Martin, M. H. 1986: The woodlouse Porcellio scaber as a 'biological indicator' of zinc, cadmium, lead and copper pollution. - Environ. Poll. Ser. B 11:271-290.

Hunter, B. A. \& Johnson, M. S. 1982: Food chain relationships of copper and cadmium in contaminated grassland ecosystems. - Oikos 38:108-117.

Hunter, B. A., Johnson, M. S. \& Thompson, D. J. 1987: Ecotoxicology of copper and cadmium in a contaminated grassland ecosystem. II. Invertebrates. - J. Appl. Ecol. 24:573-586.

Hynninen, V. 1983: Rahkasammalsiirrosten (sammalpallojen), männyn versojen ja seinäsammalen raskasme- tallipitoisuudet Harjavallan kaupungissa ja lähiympäristössä 6.1981 ja 3.1982 välisenä aikana. — Manuscript, Univ. Helsinki, Dept. Botany. 99 pp.

Juutinen, P. 1967: Zur Bionomie und zum Vorkommen der roten Kiefernbuschhornblattwespe (Neodiprion sertifer Geoffr.) in Finnland in den Jahren 1959-65. - Commun. Inst. Forest. Fennicae 63(5):1-129.

Kangas, E. 1941: Beitrag zur Biologie und Gradation von Diprion sertifer Geoffr. (Hym., Tenthredinidae). Ann. Entomol. Fennici 7:1-31.

Lindqvist, L. 1988: Transport av kadmium från växter till insekter in en terrester miljö. - Entomol. Tidskr. 109:119-122.

Maeta, Y., Kurihara, M. \& Hara, K. 1981: Biological and histological studies on the ovarian development of the European pine sawfly Neodiprion sertifer Geoffroy (Hymenoptera, Diprionidae). - Kontyo 49:577-596.

Olofsson, E. 1987: Mortality factors in a population of Neodiprion sertifer (Hymenoptera: Diprionidae). Oikos 48:297-303.

Pihlajamäki, J., Väänänen, V.-M., Koskinen, P.\& Nuorteva, P. 1989: Metal levels in Laothoe populi and Sphinx pinastri (Lepidoptera, Sphingidae) in Finland. - Ann. Entomol. Fennici 55:17-21.

Pschorn-Walcher, H. 1982: Unterordnung Symphyta, Pflanzenwespen. - In: Schwenke, W. (ed.): Die Forstschädlinge Europas, 4. Band. Hautflügler und Zweiflügler: 4-196. Hamburg \& Berlin.

van Straalen, N. M. \& van Wensem, J. 1986: Heavy metal content of forest litter arthropods as related to body-size and trophic level. — Environ. Poll. Ser. A 42:209-221.

Viitasaari, M.\& Varama, M. 1987: Sahapistiäiset 4. Havupistiäiset (Diprionidae). (Summary: Sawflies 4. Conifer sawflies (Diprionidae)). — Univ. Helsinki, Dept. Agric. Forest Zool., Rep. 10:1-79.

Received 29.VI.1989 